\title{
NOVITATES GABONENSES 63. ILLIGERA CAVA (HERNANDIACEAE), A NEW SPECIES FROM GABON AND CONGO (BRAZZAVILLE)
}

\author{
F.J. BRETELER \& J.J. WIERINGA
}

Nationaal Herbarium Nederland, Wageningen University branch (Herbarium Vadense), Biosystematics Group, Wageningen University, Generaal Foulkesweg 37, 6703 BL Wageningen, The Netherlands.e-mail: frans@breteler.demon.nl, Jan.Wieringa@wur.nl

\section{SUMMARY}

Illigera cava, endemic to Lower Guinea, is described, illustrated, and mapped. The new taxon brings the number of African Illigera species to four. Maps, and a key to the four species of Africa are presented.

Key words: Hernandiaceae, Illigera, new species, Africa, Lower Guinea.

\section{INTRODUCTION}

Illigera, a genus of c. 18 species (Kubitzki 1969), is hitherto known from continental Africa by three species: I. pentaphylla Welw. (1869), ranging from Sierra Leone in the west to Kenya in the east; I. vespertilio (Benth.) Baker f. (1925), based on Dioscorea vespertilio Benth. (1849), from Sierra Leone to West Ghana and in south Cameroon and Gabon; and I. madagascariensis H.Perrier (1927), with a few collections from Tanzania (Verdcourt 1967). The opinion of Baker f., that I. vespertilio is the older name for the former single species I. pentaphylla (sensu Sprague 1909-1910), was followed by Boutique (1951). Keay (1952), however, demonstrated that both names represent distinct species, which can easily be separated from one another by their leaf characters. One of these is the number of leaflets, three in I. vespertilio or usually five in I. pentaphylla. This may fit the material from the Flora of West Tropical Africa area (Keay 1954: 58-60), but, in Gabon at least, 5-foliolate leaves are also present in flowering I. vespertilio (A.M.Louis et al. 947).

The new species described below was recently discovered in the Chaillu Massif in South Gabon. It is mentioned in the checklist of Gabonese Vascular Plants (Sosef et al. 2006: 195) under the provisional name I. cava. Three collections from the Mayombe in SW Congo (Brazzaville) proved to belong to the new species as well. At the end of this paper a key to the now four species of continental Africa is presented.

In addition a map (Map 1) of these four species is presented. It is based on all material present in the WAG database (being all material from WAG, but for I. vespertilio also all material present in $\mathrm{K}$ and $\mathrm{BR}$ is included) to which geographically selected material cited by either Keay (1952) or Kubitzki (1969) has been added. In addition also the material from east Africa present in $\mathrm{K}$ has been added. Illigera vespertilio seems to 


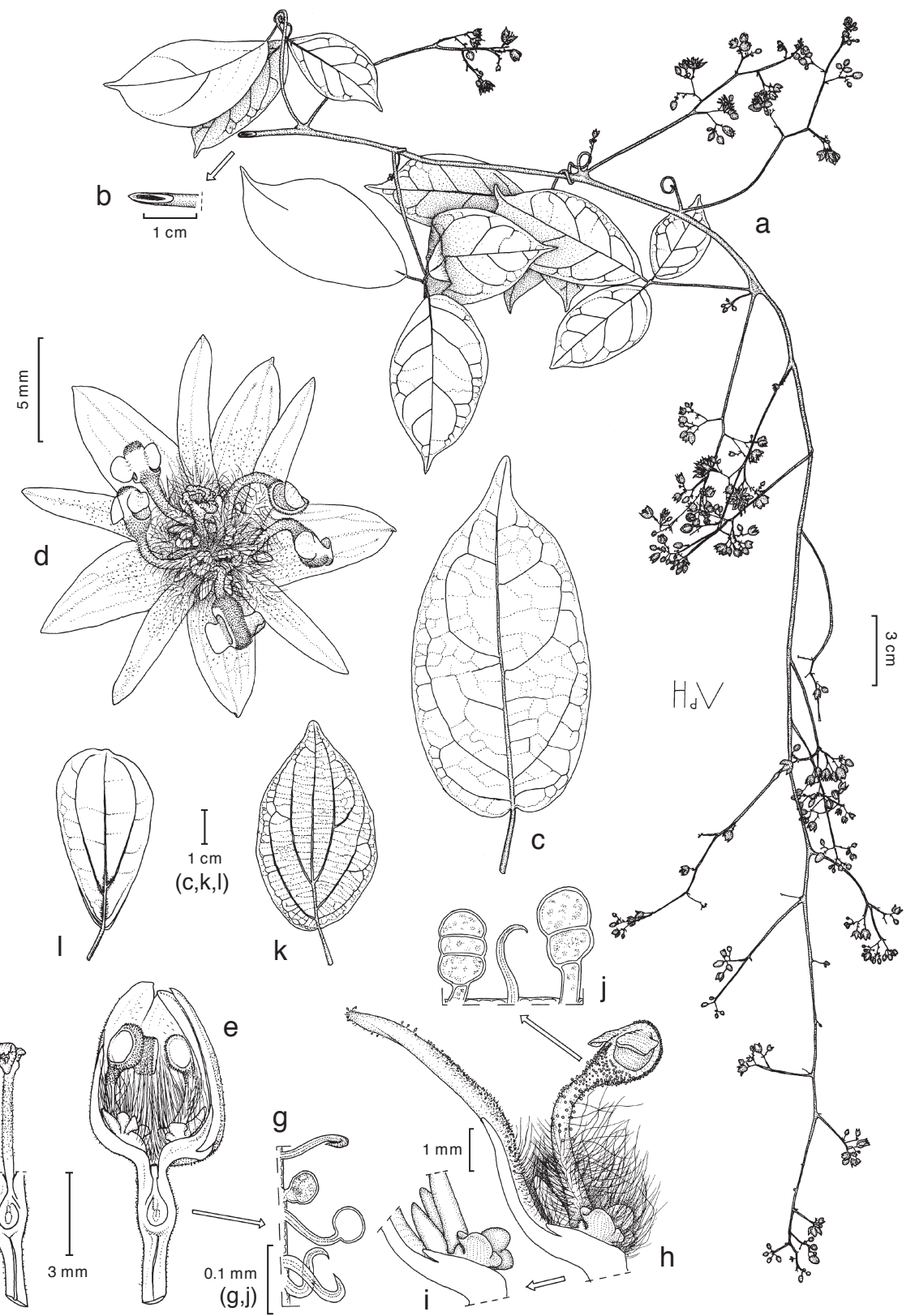

Fig. 1. Illigera cava Breteler \& Wieringa. a. Flowering branch; b. detail of hollow branchlet; c. leaflet from beneath; d. flower; e. flowerbud cut lengthwise; f. pistil; g. detail of ovary indumentum; h. detail of flower with sepal, stamen, appendages, and inter-staminal glands; i. stamen appendages and interstaminal glands without hairs; $\mathrm{j}$. detail of indumentum of filament. - Illigera pentaphylla Welw. k. Leaflet from beneath. - Illigera vespertilio (Benth.) Baker f. 1. Leaflet from beneath. (a-j: Wieringa, Nzabi \& Boussiengui 4407; k: Wieringa, Nzabi \& Boussiengui 4634; 1: A.M. Louis, Breteler \& de Bruijn 947). 
be restricted to the wetter forests: Sierra Leone to SW Ghana, only reappearing again in southern Cameroon and Gabon. Illigera pentaphylla occurs in a zone adjacent to that of I. vespertilio, but in drier forests, occurring up to the forest-savannah transition. It ranges from around the wet forests of Sierra Leone, Guinea and Liberia, over Ghana, thereby evading the wettest parts, is scarcely present in Nigeria and more or less continuously from Cameroon to eastern Kenya and eastern Tanzania in the east and to northern Angola in the south, but again evading the wettest forests in coastal Cameroon and Gabon. It is striking that I. pentaphylla does occur on the usually very wet mountain slopes of Mt Cameroon and Bioco, possibly it only occurs on slopes that lie in the rain shadow of these mountains. The Chaillu Massif in southern Gabon is the only place where all three species have been encountered in a relatively small area, although I. vespertilio in a wetter part than the other two.

\section{Illigera cava Breteler \& Wieringa, spec. nov. - Fig. 1; Map 1}

I. pentaphylla Welw. foliis acuminatis et amplitudine florum maxime simile, sed ab ea ramunculis cavis et nervatione foliorum pinnata nervis lateralibus pluribus differt. - Type: Wieringa, Nzabi \& Boussiengui 4407 (holo WAG (incl. spirit sample); iso LBV \& 5 others to be distributed), Gabon, Ngounié, $3 \mathrm{~km}$ on the road branching off near Ikobey to Magonga. $1^{\circ} 02.39 ' \mathrm{~S}, 10^{\circ} 57.28^{\prime} \mathrm{E}$, alt. $200 \mathrm{~m}, 25$ November 2001 (in flower).

Liana up to $15 \mathrm{~m}$ high, climbing by winding its petioles and petiolules. Branchlets becoming hollow, sparsely pubescent, glabrescent, hairs hooked. Leaves 3-foliolate; petiole 4-13 cm long, \pm glabrous; petiolules semiterete to canaliculate above, (3-)8-15(-20) $\mathrm{mm}$ long, glabrous to pilose above, glabrous beneath, both petiolules and petioles winding; lamina ovate-elliptic, $1.5-2(-2.5)$ times as long as wide, $(5-) 8-10(-12)$ by $(2.5-) 4-6(-8) \mathrm{cm}$, glossy both sides, cordate to rounded at base, acuminate, acumen $0.5-1.5 \mathrm{~cm}$ long with rounded and often sparsely pubescent apex; lateral nerves 4-6 pairs, plane to slightly prominent both sides, sometimes reddish below, midrib \pm plane and often pilose above, prominent and glabrous to sparsely puberulous in basal part beneath, lamina otherwise glabrous both sides to sparsely pilose beneath. Inflorescence up to c. 50-flowered, axillary and/or arranged in an up to c. $50 \mathrm{~cm}$ long terminal, compound inflorescence, sparsely puberulous, hairs \pm hooked; bracts \pm elliptic to narrowly oblong-linear, up to c. $3 \mathrm{~mm}$ long. Pedicel (including the inferior ovary) $1.5-2(-2.5)$ mm long, \pm 4 -angled, subappressed-pubescent, hairs partly hooked, partly glandular (Fig. 1g); sepals (see note) shortly united at base, \pm spreading, ovate-elliptic, $5-7$ by 3-4 mm, 5-nerved, outside very pale green, sparsely glandular- and hooked-hairy, inside white, glandular-hairy in upper part, long-hairy in basal part; petals narrowly elliptic, about as long as the sepals, c. $1.5 \mathrm{~mm}$ wide, 3-nerved, white, glabrous outside, inside with a similar indumentum as on the sepals inside; stamens 4-6 mm long, filaments glandular-hairy in upper part, long-pilose in lower part; anthers pale green, glandularhairy, opening by two valves, c. $2 \mathrm{~mm}$ long; basal appendages flask-shaped, 1-1.5 mm long, yellow, glabrous; inter-staminal glands \pm 3-lobed, \pm flat, c. $1 \mathrm{~mm}$ diam., glabrous; ovary inferior, 4-angled; style shorter than the stamens, white, glandular-hairy; stigma irregularly 3-5-lobed. Fruit unknown.

Distribution - Gabon, Congo (Brazzaville). 


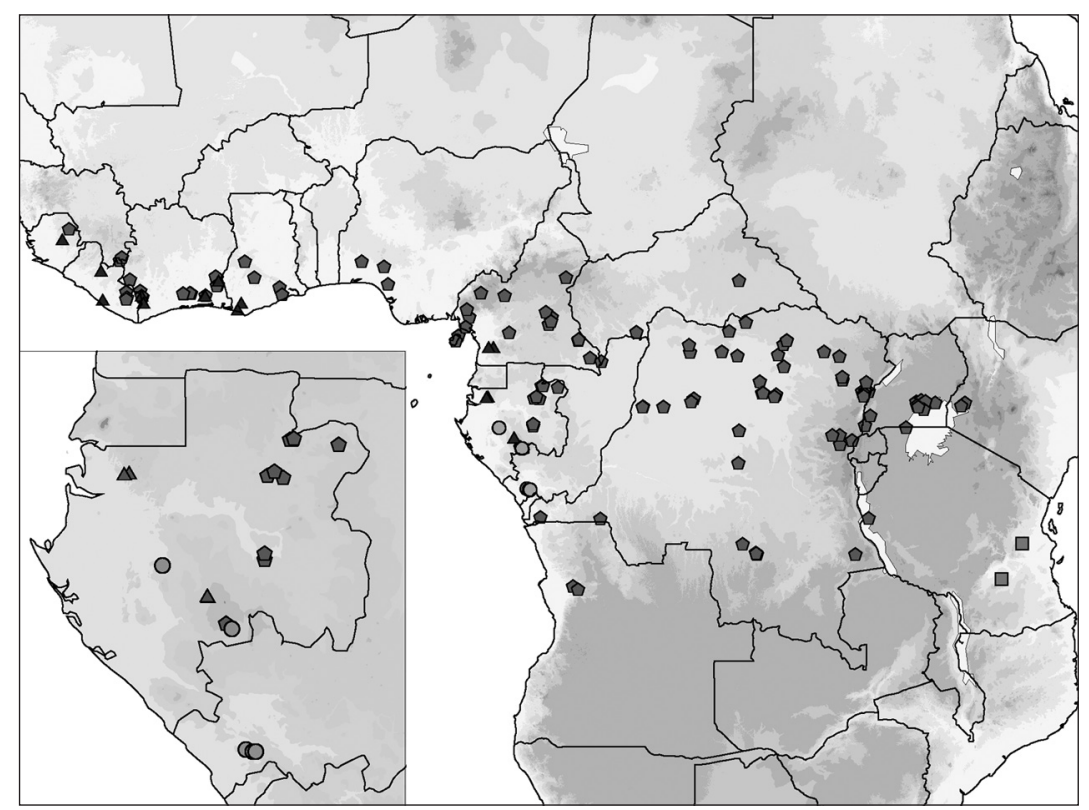

Map 1. Distribution of Illigera in continental Africa. Illigera cava Breteler \& Wieringa (•); Illigera pentaphylla Welw. (-); Illigera madagascariensis H.Perrier ( $)$ (this species is also present in eastern and northern Madagascar); Illigera vespertilio (Benth.) Baker f. (A).

Habitat \& Ecology - Rain forest, 200-700 m altitude, flowering from late November to early January.

Etymology - The epithet 'cava' refers to the hollow branchlets.

Note - The flower envelope can easily be separated into two alternate whorls of five elements each, the outer distinctly larger and 5-nerved, the inner smaller and 3-nerved. Therefore the description indicates them as sepals and petals, not as tepals. Vercourt (1985) uses tepals in his descriptions, but sepals and petals in his illustration of Illigera.

Additional material examined (paratypes):

Congo (BRAZZAVILle): Attims 47 (BR,WAG), Col du Bamba, Mayombe, 6 Jan. 1969; La Croix 5028 (BR), Niari region, Col du Bamba, 8 Dec. 1990; Sita 3120 (WAG), Mayombe, piste Dimonika - Makaba, 11 June 1971. - GABON: Wieringa, Nzabi \& Boussiengui 4647 (WAG), 50 km on road M'bigou to Malinga, 8 Dec. 2002.

The four species of Illigera from Africa may be distinguished as follows:

1a. Filament appendages urceolata, 2-4 $\mathrm{mm}$ long, shortly stipitate at base; leaves 3-foliolate; sepals and petals 7-11 mm long (specimens from continental Africa have generally larger flowers than those from Madagascar); fruits 2-4-winged. - Western Tanzania and Madagascar. . . . . . . . . . I. madagascariensis

b. Filament appendages solid, up to $1 \mathrm{~mm}$ long; leaves 3-5-foliolate; sepals and petals 5-8 mm long; fruits (unknown for I. cava) 2-winged . . . . . . . . . . 2 
2a. Branches soon becoming hollow; leaves 3-foliolate, leaflets acuminate, penninerved with 4-6 pairs of main lateral nerves; pedicel (inferior ovary) with hooked and glandular hairs (Fig. 1g). - Gabon, Congo (Brazzaville) . . . . . . . . I. cava

b. Branches remaining solid; leaves 3-5-foliolate, leaflets acuminate or not, with 1-3 pairs of main lateral nerves usually in basal half; pedicel (inferior ovary) sub-

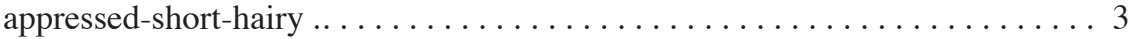

3a. Leaflets acuminate; main lateral nerves 2 (or 3) pairs (Fig. 1k). - Guinea-Congolian region, Uganda, eastern Kenya and eastern Tanzania . . . . . . . . I. pentaphylla

b. Leaflets at apex obtuse to widely emarginate, rarely rounded; main lateral nerves 1 (or 2) pairs (Fig. 11). - Upper and Lower Guinea. . . . . . . . . . I. vespertilio

\section{ACKNOWLEDGEMENTS}

We are grateful to H. de Vries for the excellent detailed drawing of I. cava and to R.H.M.J. Lemmens for the translation to Latin of the species diagnosis. We would also like to thank Barbara Mackinder (Kew) for giving valuable comments on the manuscript and for providing us with distribution details for east Africa.

\section{REFERENCES}

Baker, E.G. 1925. Notes from the British Museum Herbarium. J. Bot. 63: 174.

Bentham, G. 1849. Dioscorideae. In: W.J. Hooker, Niger Flora: 535-539. (Reprint 1966. Cramer, Lehre.)

Boutique, R. 1951. Hernandiaceae. Flore du Congo Belge et du Ruanda-Urundi 2: 446-449. I.N.E.A.C., Brussels.

Keay, R.W.J. 1952. Revision of the Flora of West Tropical Africa I. Kew Bull. 1952: 149-165.

Keay, R.W.J. 1954. Flora of West Tropical Africa, 2nd ed., 1, 1. Crown Agents for Oversea Governments and Administrations, London.

Kubitzki, K. 1969. Monographie der Hernandiaceen. Teil II. Bot. Jahrb. Syst. 89: 149-209.

Perrier de la Bâthie, J.M.H.A. 1927. Les genres Illigera et Antiaris à Madagascar. Arch. de Bot., Bull. 1: 69-71.

Sosef, M.S.M., J.J. Wieringa, C.C.H. Jongkind, G. Achoundong, Y. Azizet Issembé, D. Bedigian, R.G. van den Berg, F.J. Breteler, M. Cheek, J. Degreef, R.B. Faden, P. Glodblatt, L.J.G. van der Maesen, L. Ngok Banak, R. Niangadouma, T. Nzabi, B. Nziengui, Z. S. Rogers, T. Stévart, J.L.C.H. van Valkenburg, G. Walters \& J.J.F.E. de Wilde. 2006. Checklist of Gabonese vascular plants. Scripta Botanica Belgica 35: 1-438.

Sprague, T.A. 1909-1910. Hernandiaceae. In: K.C.M.G. Thiselton-Dyer, Flora of Tropical Africa VI, 1: 189-193. Reeve \& Co., London.

Verdcourt, B. 1967. Notes on East African Hernandiaceae: I. Kew Bull. 21: 252-258.

Verdcourt, B. 1985. Hernandiaceae. In: R.M. Polhill (ed.), Flora of Tropical East Africa: 1-12. Balkema, Rotterdam/Boston.

Welwitsch, F. 1869. Sertum Angolense. Trans. Linn. Soc., Bot. 27, 1: 1-94. 